\title{
PENGARUH PENERAPAN METODE ANDRAGOGI TERHADAP TINGKAT PENDIDIKAN, KEAKTIFAN KERJA DAN HASIL PANEN PADI PADA SEKOLAH LAPANG PENGENDALIAN HAMA TERPADU (SLPHT) DI DISTRIK AIMAS KABUPATEN SORONG
}

\author{
Sutardi $^{1)}$ dan Virman ${ }^{2)}$ \\ ${ }^{1)}$ Alumni Program Studi Magiter Pendidikan IPA Universitas Cenderawasih \\ ${ }^{2)}$ Dosen Magister Pendidikan IPA Universitas Cenderawasih
}

\begin{abstract}
This study examines the effect of the application of the method to focus Andragogy the level of education, active labor and the harvest on Integrated Pest Management Field School (FFS) in District Aimas Sorong Regency. Implementation of this research was conducted in three groups of farmers in the district forward Aimas ie farmer groups of 25 people, farmer groups and the border of the farmer 25 farmer groups Rukun Wargi 25 people that totaled 75 people. This research is experimental real. For the regression test results of this study indicate that there is a significant contribution between andragogy methods the education level of $0.4 \%$, a simple regression test results showed that, Andragogy method to work activeness of $1.2 \%$, while for methods of andragogy against varabel harvest rice result of 45.7\%. Based on the results of this study concluded that there is the influence of the simultaneous application of the method Andragogy the level of education, active labor and the harvest on Integrated Pest Management Field School (FFS) in District Aimas Sorong Regency.
\end{abstract}

Keywords: Methods andragogy, level of education, employment and results activeness rice harvest

\begin{abstract}
Abstrak. Penelitian ini secara fokus mengkaji pengaruh penerapan metode andragogi terhadap tingkat pendidikan, keaktifan kerja dan hasil panen padi pada Sekolah Lapang Pengendalian Hama Terpadu (SLPHT) di Distrik Aimas Kabupaten Sorong. Pelaksanaan penelitian ini dilakukan pada 3 kelompok tani di Distrik Aimas yaitu kelompok tani maju 25 orang, kelompok tani margo tani 25 orang dan kelompok tani Rukun Wargi 25 orang sehingga berjumlah 75 orang. Penelitian ini bersifat eksperimental. Untuk uji regresi hasil penelitian ini menunjukkan bahwa terdapat kontribusi yang signifikan antara metode andragogi terhadap tingkat pendidikan $0,4 \%$, Uji regresi sederhana hasil penelitian menunjukkan bahwa, metode andragogi terhadap keaktifan kerja sebesar 1,2 \%, sedangkan untuk metode andragogi terhadap varabel hasil panen padi diperoleh hasil 45,7\%. Berdasarkan hasil penelitian dapat disimpulkan bahwa ada pengaruh secara simultan penerapan metode andragogi terhadap tingkat pendidikan, keaktifan kerja dan hasil panen padi pada Sekolah Lapang Pengendalian Hama Terpadu (SLPHT) di Distrik Aimas Kabupaten Sorong.
\end{abstract}

Kata Kunci : Metode andragogi, tingkat pendidikan, keaktifan kerja dan hasil panen padi. 


\section{PENDAHULUAN}

Sekolah Lapangan Pengendalian Hama Terpadu (SLPHT) merupakan pendekatan pembelajaran orang dewasa (Andragogi) yang diyakini sebagai salah satu upaya pemberdayaan masyarakat petani dalam kegiatan perlindungan tanaman yang mengacu pada prinsip-prinsip Pengendalian Hama terpadu (PHT). Pengendalian Hama Terpadu merupakan suatu Kebijakan Nasional dalam Perlindungan Tanaman Pangan, yang merupakan suatu pendekatan yang ampuh. Seperti halnya selama ini dengan penggunaan pestisida yang kurang bijaksana, banyak menimbulkan dampak negatif seperti terjadinya resistensi hama bahkan menimbulkan resurgensi sehingga ekosistem tidak stabil. Dalam hal ini petani sebagai pengelola usaha tani maka perlu dibekali ilmu tentang pengendaliaan hama terpadu sehingga petani tidak tergantunng pada pemakaian pestisida, namun petani lebih banyak melakukan pendekatan ekologi dan pengelolaan ekosistem.

Organisme Pengganggu Tanaman (OPT) merupakan faktor penentu dalam budidaya tanaman guna pencapaian produksi yang maksimal. Salah satu langkah pemerintah guna memenuhi permasalahan tersebut adalah dengan adanya Sekolah Lapangan Pengendalian Hama Terpadu (SLPHT) padi bagi petani..

Menurut Sumantri (2007:23) ragam minat orang sangat banyak dilihat dari jumlahnya, minat - minat yang sangat beragam jumlahnya itu dapat dibagi dalam tiga kategori, yaitu : minat pribadi, minat rekreasi, dan minat sosial. Selanjutnya menurut Dugan Laird (Hendayat S. 2005 : 135) mengatakan bahwa andragogi mempelajari bagaimana orang dewasa belajar. Laird yakin bahwa orang dewasa belajar dengan cara yang secara signifikan berbeda dengan cara-cara anak dalam memperoleh tingkah laku baru.

Pendidikan andragogi di Indonesia belum mencapai standar yang diinginkan, padahal untuk memajukan ilmu pengetahuan dan teknologi (IPTEK) sains penting dan menjadi tolak ukur kemajuan bangsa. Kenyataan yang terjadi di Indonesia, mata plajaran andragogi tidak begitu diminati dan kurang diperhatikan. 
Apalagi melihat kurangnya pendidik yang menerapkan konsep andragogi.

Pendidikan andragogi merupakan disiplin ilmu yang di dalamnya terkait antara pendidikan dengan andragogi. Pendidikan merupakan suatu proses sadar dan terencana dari setiap individu maupun kelompok untuk membentuk pribadi yang baik dalam mengembangkan potensi yang ada dalam upaya mewujudkan cita-cita dan tujuan hidup yang diharapkan. andragogi sendiri merupakan pengetahuan dari hasil kegiatan manusia yang dipeoleh dengan menggunakan langkah-langkah ilmiah yang berupa metode ilmiah yang didapatkan dari hasil eksperimen atau observasi yang bersifat umum sehingga akan terus disempurnakan.

Sekolah lapangan pengendalian hama terpadu merupaka terobosan dalam meningkatkan sumberdaya petani, dengan demikian maka perlu dilakukan sosialisasi ke masyarakat. Penerapan metode andragogi terhadap tingkat pendidikan, keaktifan kerja dan hasil panen padi perlu dilakukan dalam penelitian ini.

Tujuan Penelitian (1)Untuk mengetahui pengaruh penerapan metode andragogi terhadap tingkat pendidikan bagi petani padi di Distrik Aimas Kabupaten Sorong. (2)Untuk mengetahui pengaruh penerapan metode andragogi terhadap keaktifan kerja petani dalam meningkatkan hasil panen padi di Distrik Aimas Kabupaten Sorong.(3) Untuk mengetahui pengaruh penerapan metode andragogi terhadap hasil panen petani padi di Distrik Aimas Kabupaten Sorong. 


\section{METODE PENILITIAN}

Desain dalam penelitian ditunjukkkan pada gambar 1 berikut ini :

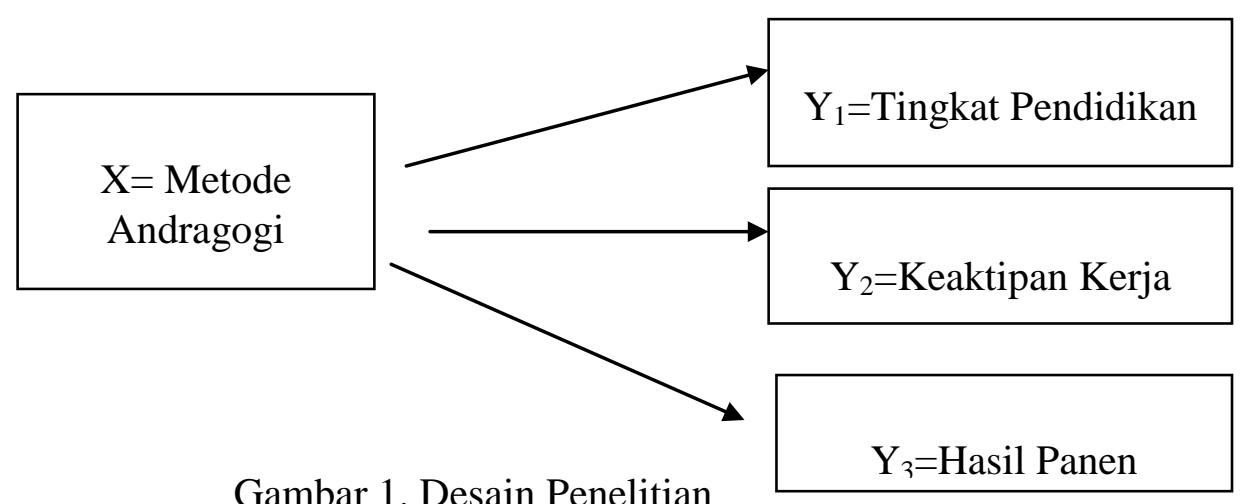

Menurut (Suharsini Arikunto 2006

: 102) Populasi adalah keseluruhan subjek penelitian. Dalam penelitian ini yang dijadikan populasi adalah seluruh kelompok tani Aimas yang terdiri dari kelompok tani dan masing masing berjumlah 25 orang sehingga berjumlah $3 \times 25=75$ Orang.

Sampel adalah bagian dari populasi yang diambil sebagai subjek penelitian dengan menggunakan caracara tertentu ( Sudjana, 1992 : 15 ) Untuk menentukan sampel penulis mengacu pada ketentuan yang di kemukaan oleh Suharsimi Arikonto (2006:107) bahwa subjek $\leq 100$ maka sampel diambil semua. Jadi penelitian ini menggunakan sampel keseluruhan kelompok tani Aimas yang jumlahnya 75 orang terdiri dari 3 Kelompok tani masing masing berjumlah 25 orang sehingga berjumlah $3 \times 25=75$ Orang.

\section{PEMBAHASAN}

Uji normalitas data peserta Sekolah Lapang Pengendalian Hama Terpadu (SLPHT) menunjukkan bahwa metode andragogi sig $>0,140$; variabel hasil belajar sig $>0,396$; Keaktifan kerja sig $>0,583$ dan hasil belajar sig $>$ 0,214. Hal ini berarti bahwa data memiliki kecenderungan distribusi secara normal. Penerapan metode andragogi berdistribusi normal, tingkat pendidikan berdistribusi normal, keaktifan kerja berdistribusi normal dan hasil panen petani padi berditribusi normal.

Hasil pengujian hipotesis menyatakan bahwa pengaruh metode andragogi terhadap tingkat pendidikan 
hasil belajar relatif kecil sebesar 0,191, sehingga diperoleh model regresi $\hat{y}=$ 84,918 - 0,191x .Sehingga walaupun tingkat pendidikan yang beragam, metode andragogi tidak berpengaruh secara significan. Koefisien determinasi dapat dilihat dari nilai $\mathrm{R}$ square sebesar 0,004 yang artinya $0,4 \%$ variabel tingkat pendidikan hasil belajar terhadap metode andragogi sangat relatif kecil sedangkan sisanya 99,6 \% dijelaskan oleh variabel variabel yang lainnnya.

Berdasarakan hasil penelitian menunjukkan bahwa nilai $r$ koefisien determinasi sebesar 0,212 dalam hal ini berarti ada pengaruh antara metode andragogi terhadap hasil belajar tingkat respon yang tidak sekolah sebesar 21,2\% dan hasil penelitian menunjukkan nilai $f$. hit sebesar 2,415 lebih kecil daripada $\mathrm{f}$ tabel 5,32. Sehingga dapat disimpulkan bahwa hipotesis ditolak atau tidak ada hubungan antara metode andragogi terhadap tingkat pendidikan. Diperoleh persamaan regresi $\hat{Y}=181,602-1,369 x$ Dari hasil pengujian hipotesis menyatakan bahwa pengaruh metode andragogi terhadap tingkat pendidikan hasil belajar relatif kecil sebesar 1,369, Sehingga walaupun hasil belajar yang beragam, metode andragogi tidak berpengaruh secara significant. Tampak Uji t tabel -1,554 ternyata $<$ darpada $\mathrm{t}$ tabel sebesar 1,833 sehingga keeratan hubungan antara metode andragogi terhadap hasil belajar relatif kecil.

Nilai $r$ koefisien determinasi sebesar 0,012 dalam hal ini berarti ada pengaruh antara metode andragogi terhadap keaktifan kerja tingkat respon yang tidak sekolah sebesar 1,2\% , sedanggkan nilai f. hit sebesar 0,106 lebih kecil daripada $\mathrm{f}$ tabel 5,32. Sehingga dapat disimpulkan bahwa hipotesis ditolak atau tidak ada hubungan antara metode andragogi terhadap keaktifan kerja.

Persamaan regresinya adalah $\hat{\mathrm{Y}}=$ $73,008+0,145 x$ dan pengujian hipotesis menyatakan bahwa pengaruh metode andragogi terhadap keaktifan kerja relatif kecil sebesar 0,145. Sehingga walaupun keaktifan kerja yang beragam, metode andragogi tidak berpengaruh secara significant. Tampak Uji t tabel 0,325 ternyata $<$ darpada t tabel sebesar 1,833 sehingga keeratan hubungan antara metode andragogi terhadap keaktifan kerja relatif kecil. 
Berdasarkan hasil penelitian menunjukkan bahwa nilai $\mathrm{r}$ koefisien determinasi sebesar 0,457 dalam hal ini berarti ada pengaruh antara metode andragogi terhadap hasil panen tingkat respon yang tidak sekolah sebesar 45,7 $\%$ dan nilai $\mathrm{F}$. hit sebesar 7,564 > daripada F tabel 5,32. Sehingga dapat disimpulkan bahwa hipotesis diterima atau terdapat pengaruh antara metode andragogi terhadap hasil panen padi. Persamaan regresi diperoleh $\hat{\mathrm{Y}}=22,629$ - 0,214x dan hasil pengujian hipotesis menyatakan bahwa pengaruh metode andragogi terhadap hasil panen relatif kecil sebesar 0,214. Sehingga walaupun hasil panen yang beragam, metode andragogi berpengaruh secara significant. Tampak Uji t. hit - 2,75 ternyata $<$ darpada t tabel sebesar 1,833 sehingga keeratan hubungan antara metode andragogi terhadap keaktifan kerja relatif kecil, disajikan dalam sig hit $<0,022$ dari $\alpha=0,05$.

Berdasarkan hasil penelitian menunjukkan bahwa nilai $\mathrm{r}$ koefisien determinasi sebesar 0,457 dalam hal ini berarti ada pengaruh antara metode andragogi terhadap hasil panen tingkat respon yang tidak sekolah sebesar $45,7 \%$.
Berdasarkan hasil penelitian menunjukkan nilai $\mathrm{F}$. hit sebesar 0,561 $<$ daripada F tabel 4,3. Sehingga dapat disimpulkan bahwa hipotesis diterima atau terdapat pengaruh antara metode andragogi terhadap hasil panen padi. Persamaan regresi $\hat{Y}=11,114$ 0,076x dan pengujian hipotesis menyatakan bahwa pengaruh metode andragogi terhadap hasil panen relatif kecil sebesar 0,076. Sehingga walaupun hasil panen yang beragam, metode andragogi berpengaruh secara significant. Tampak Uji t tabel - 0,749 ternyata $<$ darpada $\mathrm{t}$ tabel sebesar 1,714 sehingga keeratan hubungan antara metode andragogi terhadap hasil panen sangat signifikan, disajikan dalam sig hit $>0,462$ dari $\alpha=0,05$.

\section{SIMPULAN DAN SARAN SIMPULAN}

Sesuai dengan penelitian yang telah dilakukan dan pembahasannya mengenai pengaruh metode andragogi terhadap tingkat pendidikan, keaktifan kerja dan hasil panen padi pada Sekolah Lapang Pengendalian Hama Terpadu (SLPHT) di Distrik Aimas Kabupaten Sorong, maka diperoleh kesimpulan sebagi berikut 
1. Ada pengaruh positif yang signifikan antara metode andragogi terhadap tingkat pendidikan petani melalui pengujian parsial sebesar $0,4 \%$.

2. Ada pengaruh positif yang signifikan antara metode andragogi terhadap keaktifan kerja melalui pengujian parsial sebesar 1,2\%.

3. Ada pengaruh positif yang signifikan antara metode andragogi terhadap hasil panen padi melalui pengujian parsial sebesar rata rata sebesar $45,7 \%$.

\section{SARAN}

Dengan mengetahu pengaruh yang positif antara metode andragogi terhadap tingkat pendidikan, keaktifan kerja dan hasil panen padi secara simultan maupun parsial, maka penulis menyarankan :

1. Bagi petani dapat mensosialisasikan metode andragogi pada sekolah lapang pengendalian hama terpadu (SLPHT). Agar dalam membudidayakan tanaman padi selalu memperhatikan kondisi ekosistem yang ramah lingkungan, dengan hasil panen yang tinggi
2. Bagi instansi terkait perlu pemberdayaan dan peningkatan sumberdaya manusia di tingkat petani melalui metode andragogi pada Sekolah Lapang Penegndalian Hama Terpadu (SLPHT).

3. Bagi praktisi pertanian perlu adanya pengembangan teknologi dalam budidaya tanaman sehat, pemanfaatan musuh alami, pengamatan secara rutin/berkala dan petani sebagai ahli Pengendalian Hama Terapadu.

\section{DAFTAR PUSTAKA}

Ansory, Ikhsan. 2002. Pengantar Pendidikan. Edisi Pertama. Malang: UMM Press.

Anitah W, Sri, dkk. 2007, Strategi Pembelajaran Kimia. Cetakan 1. Jakarta: Iniversitas Terbuka.

Arikunto, Suharsimi. 2006. Prosedur Penelitian Suatu Pendekatan Praktik. Edisi revisi VI. Jakarta: PT Rineka Cipta.

Andragogi (Sebuah Konsep Teoritik), $\quad$ http://www.esmartschool.com/ sptPendidikan/ artikel13.asp

Arif, Zainuddin.

(1994). Andragogi. Bandung: Angkasa.

Dharmawan. 2008. Discoveri Inquiry Sebuah Metode. http://dadhar.blogspot.com/ 2008/02/ 
8 Jurnal Ilmu Pendidikan Indonesia, Volume 5, Nomor 2, Edisi Juni 2017, Hal 1 - 8

discovery -inquiry-sebuah- metode.html 14 Maret 2009.

Hikamawan, Rusydi. Andragogi, Pendidikan Untuk Pendewasaan, http://pelajarislam. wordpress.com /2007/10/23/ andragogi-pendidikanuntuk-pendewasaan/, 23 Oktober 2007.

Lunandi, A, G. (1987). Pendidikan orang dewasa. Jakarta: Gramedia.

Partino, H. R. 2008. Metodologi Penelitian Kuantitatif. Edisi pertama, Cetakan ketiga. Yogyakarta: Pustaka Mahasiswa.

Ridwan. 2008. Ketercapaian Prestasi Belajar. http://ridwan202.wordpress.com/ 2008/05/03/ ketercapaian- prestasibelajar 2 April 2009
Sunaryo, Hari. 2002. Strategi Belajar Mengajar. Edisi pertama. Malang: UMM Press.

Sudjana. 2005. Strategi Pembelajaran. Bandung: Falah Production Tom Nesbit, Linda Leach \& Griff Foley .2004. Adult Education.

Sumantri, Ating.2006. Aplikasi

Statistik Dalam Penelitian.Edisi

pertama. Bandung: Pustaka Setia

Sidjabat, B, S. Prinsip Pedagogi dan Andragogi dalam Pembelajaran, http://www .tiranus .net/ ?p =20, Diakses 10 Maret 2008.

S, Bambang., Lukman. Kelemahan dan Keunggulan Teori Belajar Andragogi, http://www.geocities.com/teknologipem belajaran/andragogi.html

http://www.jugaguru.com/article/4 9/tahun/2006/bulan/10/tanggal/10/id/18 4/ 